\title{
The 15 July 2016 Failed Coup and the Security Sector
}

\author{
Yaprak Gürsoy
}

Since the Justice and Development Party (AKP) came to power in 2002, reforms of the security sector, and especially civil-military relations, have been a priority for the government. In this period of more than a decade, the powers, autonomy and functions of key institutions in the security sector have been redefined with legal amendments. Some of the reforms in the area of civil-military relations brought the Turkish legal structure close to a democratic framework. The reforms, along with major observable changes in the behavioural patterns of military officers, gave the impression that the armed forces were out of politics and subjugated to civilian powerholders.

Yet, the events of the night of 15 July 2016, when Turkey experienced an unanticipated coup attempt against the elected government, defied the conclusion that the military was out of politics. The attempt, in many respects, was the first of its kind in Turkish history. The plotters detained their commanders, including the chief of the general staff, fought against their own comrades with firearms, shot and killed unarmed civilians, and bombed the national parliament, police headquarters and the offices of the intelligence agency. The putschists surrendered to government forces within approximately 13 hours, but inflicted unprecedented damage before doing so.

How can we explain these extraordinary events in light of the security sector reforms that were made in order to prevent the history of coups in Turkey from repeating itself? To answer this question this chapter analyses the changing security frameworks of the decade prior to the coup. Through the examination of developments in civil-military relations, intelligence and police services, it shows that the government created forces loyal to itself 
and the regime. It was the existence of these forces that ultimately led to the coup's failure. In that sense, the changes of the past decade prevented a successful coup from taking place. However, it was also the events of the prior decade that sowed the seeds of the putsch by disturbing the existing balance of power between different groups and security institutions. In other words, the whole coup picture can be seen only by looking at the changes that have taken place in the security sector.

The chapter is divided into three sections. The first section discusses developments from 2007 onwards, which influenced the legal framework of the security sector and the behaviour of the actors. The aim of this section is to show how these changes unintentionally paved the way for the failed coup. The second section provides an overview of the coup itself and outline how events unfolded during the 13 hours that Turkey was on tenterhooks. In the third section, the amendments that were introduced in the military and the intelligence agency immediately after the coup are examined. The chapter concludes with a brief summary.

\section{The Context Leading Up to the Failed Coup}

The set of events that led to the failed putsch can be traced back to 2007, a turning point in Turkish politics in many respects. This is the year that the AKP won the general elections for a second time and effectively defeated the secularist resistance in the military, judiciary and civil society. This is also the year after which the Islamist movement led by Fethullah Gülen became publicly visible in matters involving the security sector. This section outlines how relations between the Gülen movement and the AKP government (first as allies, then as lethal antagonists) has shaped and reshaped the military, the National Intelligence Agency (MIT) and the police.

The Coup Plots and their Consequences for the Military 
One of the first operations that changed the Turkish security sector was the Ergenekon investigations, which began in 2007 and accused hundreds of military personnel and civilians of forming a terrorist organization and planning to stage a coup against the government (Kirkeser 2013). In 2010, another case sought to link more than 300 military officers with a coup plan called Balyoz (Sledgehammer) (Hürriyet 2012). The final investigation was the case of "military espionage", accusing around 350 suspects with blackmailing, prostitution and sharing secret information with foreign services (Karataş 2013). In 2012 and 2013, the Specially Authorized Courts that tried the Ergenekon and Balyoz cases found around 600 military and civilian suspects guilty and condemned them to prison sentences of various lengths. Among those that received life sentences were a former chief of the general staff and commanders of the armed forces (Usta and Erçiçek 2012; BBC Türkçe 2013).

Later events, however, demonstrated that the coup investigations were carried out by public prosecutors and police officers who were alleged to be part of the Gülen movement. At first the AKP government gave its blessing to the cases despite reported irregularities. In its alliance with the Gülenists, the government aimed to curb the remaining political powers and prestige of the secular military. But after the December 2013 showdown between the AKP and the Gülen movement, the AKP changed its opinion and altered the fate of the investigations. In April 2015, all Balyoz suspects were re-tried and acquitted (Hürriyet 2015). In March 2014, the Constitutional Court ruled that the rights of a number of Ergenekon suspects were violated and released all suspects from prison. The Court of Appeals overturned the previous court decision, the cases began to be retried in June 2017 and formally closed in June 2018 (TRT Haber 2017; Saymaz 2018). Finally, all suspects were acquitted in the espionage case in February 2016 (Hürriyet 2016a).

Despite the reversal of the decisions, the Turkish political system was modified in unprecedented ways through these investigations. First, the government switched sides on the 
cases in just a matter of a few years, politicizing a court matter, and thus damaging the basic principles of the rule of law and democracy. Second, in the overall domestic power structure, the military was rendered a mere shadow of its former self. In the post-1980 coup era, the armed forces had become a unified, secular, right-wing guardian of the Republic, supported by other secular citizens and institutions, such as the judiciary. ${ }^{1}$ By 2016 , however, it was neither influential nor prestigious. It was also too timid to intervene in politics, not necessarily because of principles of democracy but also because of possible coup accusations.

The final overall effect of the trials was to disturb the unity of the armed forces and its promotional patterns. The High Military Council (Yüksek Askeri Şura, YAŞ) meetings, which decide on personnel appointments and promotions, began to be controlled by the government after August 2010, when the chief of the staff resigned due to a dispute over the court cases (Hürriyet 2016b). From this YAŞ meeting onwards, positions that were vacated as a result of purges in the military following the coup investigations were filled by alleged Gülen affiliates, who played critical roles on the night of 15 July. According to one calculation, for instance, among the 46 names that were promoted from colonel to brigadier admiral in the navy between 2010 and 2015, 23 of them were implicated in the putsch. In other words, half of those who were promoted in the middle ranks are now either arrested or are fugitives. This outcome occurred in a context where around 140 navy colonels were bypassed because they were suspects especially in the Balyoz and espionage cases (Ergin 2016a). A similar situation also occurred in the air force. An overview of the 2012 promotions, for instance, shows that only two of the nine colonels that were promoted to brigadier general were not later implicated in the 15 July attempt (Ergin 2016b).

Based on these numbers, arguably the cases cleared the path for some Gülenist officers in the middle ranks by phasing out possible secularist officers. The evidence also indicates that the dominance of the secularists in the upper and middle ranks of the armed 
forces was broken. In short, the trials changed the military in fundamental ways preparing the path for the coup outcome.

New Laws on Intelligence, the Gendarmerie and the Police

The conflict between the Gülen movement and the AKP also had consequences for the National Intelligence Agency (Milli İstihbarat Teşkilatı, MíT) and police. Indeed, the struggle between the former allies became public in events that involved these security forces. On 17 December 2013 alleged Gülen prosecutors began a corruption investigation that implicated government ministers. Next month, the prosecutor's office stopped trucks supposedly carrying arms to the Syrian rebels. The gendarmerie forces and the prosecutor's office wanted to search the trucks, but MiT agents did not allow it (Hamsici 2017).

The involvement of MIT in the January truck raid proved that the intelligence agency had become a loyal security service of the AKP government in general and of then Prime Minister Erdoğan in particular. It was reported that the Chief of MIT, Hakan Fidan, who was previously Erdoğan's private advisor, was taking independent action in the Middle East following the Arab uprisings and continuing to function as Erdoğan's primary aide in foreign policy (Entous and Parkinson 2013; Ignatius 2013). At home, the activities of Fidan drew attention, when in September 2011, voice records of Fidan and another MíT official were revealed attending a meeting with the leaders of the Kurdistan Workers' Party (Partiya Karkerên Kurdistanê, PKK) in Oslo two years earlier. Subsequently, in February 2012 the prosecutor responsible for investigating the activities of the alleged urban wing of the PKK, the Kurdistan Communities Union (Koma Civakên Kurdistan, KCK), called Fidan and other MIT members to testify in the case (Ceyhan 2012). 
The AKP government initially dodged the bullet by removing the Gülenist prosecutor from his position and dismissing or sending to remote parts of the country thousands of police officers. Within 10 days of the prosecutor's attempt to investigate Fidan, the law on MiT was also changed by the parliament, requiring the approval of the prime minister to prosecute the chief of MiT. The new article was applied retrospectively to all continuing investigations, freeing Fidan from any possible trial (TBMM 2012). The quick reaction of the government demonstrated the special place that MIT had been accorded in Turkish domestic and foreign policy.

In April 2014, a new law concerning MİT, envisioning more comprehensive changes in the agency's functions, was approved by parliament in order to prevent similar incidents occurring in the future. However, certain provisions of the law were criticized by opposition parties, human rights groups and other observers for creating an "intelligence state" and giving extraordinary powers to the agency (Hürriyet Daily News 2014). The duties of MIT were expanded so that the agency would be responsible for matters involving national defence, the fight against terrorism and national security. In these matters, the agency was given the right to secretly collect, analyse and record data from any individual or institution, including tapping phone calls. In addition, anyone who published leaked information regarding MIT officials and the agency's activities could receive prison sentences up to 10 years (TBMM 2014).

The MiT was not the only security sector institution that came under the spotlight following the AKP's altercation with the Gülen movement. In March 2015, the parliament passed an internal security package, with the intention of strengthening the hands of law enforcement agencies (TBMM 2015). The gendarmerie, which functions as a police force in rural areas, came under the authority of the ministry of interior more than the military. Although this might be seen as a positive development from the perspective of civil-military 
relations, the fact that governors would be able to oversee and determine the promotion and appointment of gendarmerie personnel suggested that the forces might be used to repress the opposition. It was also argued that one of the main purposes of the package was to prevent the gendarmerie being used by the judiciary in a possible attack against the interests of the government, as happened during the search of the MIT trucks in 2014 (Toker 2015).

Another set of articles in the internal security package changed laws related to the duties and authorities of the police. The articles raised serious concerns over basic democratic rights, such as taking part in peaceful organisations and freedom of speech. Some of the controversial articles in the law included the extensive discretion granted to the police in searching people and vehicles without a warrant, in using firearms and in the detention of individuals, as well as the possibility of prosecuting citizens for participation in public demonstrations and rallies (BBCTürkçe 2015; HRW 2014). The government also tried to cleanse the institution from opposition forces. Following the 2013 graft probe, 3,785 police officers were dismissed from their posts (Bulur and Çakmak 2016).

Overall, in the period following 2013 and up until 2016, the AKP government was in an all-out war against its previous ally, the Gülen movement. The government tried to cleanse the police of Gülen sympathizers while it held the MiT close, attempted to control the gendarmerie and advance individuals loyal to the regime in all security sector institutions. The final plan of action before the 15 July coup attempt was to purge Gülenist officers from the armed forces in the upcoming YAŞ meeting scheduled for August.

\section{The Coup}

As one of the most critical turning points in Turkish history, the 15 July attempt was carried out because secularists in the military lost their dominance and the unity of the armed 
forces was damaged through the promotions of Gülenists, especially to prominent middle ranks. But segments of the military top brass, as well as the MIT and the majority of the police services, had become pro-government through these changes and it was their anti-coup stance that ultimately caused the attempt to fail.

The putsch started at around 22:00 on 15 July when jets started to fly low in Ankara and the passages from the Anatolian to the European sides of Istanbul's two bridges were blocked by tanks. The coup officially came to an end at 11:00 the next morning when the First Army Commander Ümit Dündar, who had been appointed during the night as the standing Chief of Staff, declared that the coup was repelled. ${ }^{2}$ Critical moments during this 13hour period were observed by anyone who witnessed the events from their homes around Turkey. The first acknowledgment that a coup was taking place came from Prime Minister Binali Y1ldırım, when he called TV channels approximately one hour after the first incidents started. This was followed by the reading of the putschists' manifesto on the state-run TV channel at around midnight. Although at that moment the coup-plotters seemed to have the upper hand, things began to change after President Erdoğan appeared in a live broadcast on CNN Turk through FaceTime and called on citizens to go out on the streets to defend democracy. Following his appearance, prayers began to be heard from mosques all around the country, continuing throughout the night and the next morning. Meanwhile, opposition party leaders declared their disapproval of the coup and the national assembly met at 01:40 to show its unified stance against the coup. This led to the bombing of the parliament several times during the night, causing parliamentarians from various parties to go the shelter of the parliament and broadcasting live from there. At 03:20, President Erdoğan's plane landed at Istanbul's Atatürk Airport, which was being taken back from the putschists by thousands of citizens who had replied to his earlier call. President Erdoğan held a press briefing at the airport signalling the failure of the coup. Gradually putschist soldiers began surrendering 
everywhere and for most observers the coup came to an end when the symbolic Boğaziçi Bridge was taken over by citizens at 06:42.

The narration of the coup plot beyond these critical events that everyone was able to observe is difficult (Taş 2018). Questions regarding who gave the order for the coup and who was its military leader are still controversial. Shortly after the events began to unfold, government officials declared that the putsch was organized by the Gülen movement. This scenario became the most dominant account of the coup, and public opinion has converged on the view that Gülenists, now designated a terrorist organization by the Turkish state (Fethullahçı Terör Örgütü, FETÖ), were the only culprits. One of the most concrete pieces of evidence that connects the coup with the Gülenists is the capturing of five civilians and their security camera videos from the night of the coup at the Akınc1 Air Base, which functioned as the headquarters of putsch. Background information on these individuals ties them to the Gülen movement and it is alleged they visited Gülen personally several times in Pennsylvania, including a few days before the coup. ${ }^{3}$ A visit that took place in January 2016 by one of the suspects was verified with the information the US Department of Homeland Security shared with the Turkish law enforcement agencies in September 2017 (Ergin 2017c).

Gülen himself has rejected his movement's association with the coup (Gülen 2017). His denial, as well as the increasingly heavy-handed and authoritarian manner in which the government is handling matters, convinces some that the Gülenists were not behind the attempt. From this perspective, evidence could have been planted or confessions of some of the suspects might have been extracted through threats or torture. The AKP government is also in a tight spot because of its track record with previous coup plots, such as the Balyoz case, and the damage that has been caused to the rule of law in the last decade. Although 
public opinion in Turkey in the aftermath of the coup was persuaded that FETÖ carried out this heinous act in a last-ditch effort to prevent its affiliates from being dismissed from the armed forces, Turkey's NATO allies, such the USA and European powers, are not convinced (Rettman 2017; Aydıntaşbaş 2017).

There are also other controversies regarding the coup plot involving the security sector actors. According to the indictment, at 14:20 on 15 July, a major, who confessed being a former Gülenist and serving at the army aviation command post, informed MIT of the upcoming coup. In turn, MİT reported the tip off to the general staff and Hakan Fidan held a private meeting with the Chief of the General Staff Hulusi Akar. The only concrete action that came out of this meeting seems to be Akar's order for Land Forces Commander Salih Zeki Çolak to inspect the command post. Akar also closed Turkish air space to military flights for the day. Both orders of the chief of staff were obviously futile in preventing the coup, but they were still significant in alarming the plotters to take action in the early hours of the night, rather than at 3:00 as scheduled (CNNTurk 2017). This rearrangement caused major weaknesses for the pustchists and is one of the reasons why the plot failed.

However, there is controversy over whether MIT could have done more to prevent the coup. It is also unclear why MİT, which was supposed to be the most loyal security institution, did not inform the government of the impending danger, leaving the prime minister and president to narrowly escape. Based on this, there are suspicions that there might be more behind the official story. The main opposition Republican People's Party (Cumhurriyet Halk Partisi, CHP) has, for instance, suggested that this was "a controlled coup," known by the government beforehand but allowed to play out in order to reveal and repress the Gülenists (Birgün 2017; Cumhuriyet 2017). 
Notwithstanding this alternative scenario, it is clear that the coup ultimately failed because of the actions of anti-coup forces within the armed forces. The chief of staff and commanders were apprehended by the coup plotters, but the Commander of the First Army took over and announced on TV that the coup was illegal and would fail. These declarations of a top general, along with the announcements of Prime Minister Y1ldirım, President Erdoğan and leaders of the opposition parties, prevented potential officers from joining the coup. $^{4}$

In many military units throughout the country, battles were also fought between various anti-coup and pro-coup individuals and groups. Similar conflicts were experienced in the air, with the Eskişehir combined air operations centre being the key bastion of the anticoup officers (Ergin 2017d, 2017e). Coup plotters targeted their own colleagues during these battles on the ground and in the air, while also opening fire on and bombing MiT and police headquarters in Ankara, despite the presence of civilians. The balance sheet of these battles was severe. 249 people were killed and 2,196 people were wounded that night. Most casualties were civilians while 63 of those who died were policemen and three were military personnel fighting against the putschists (Posta 2017). Additional causalities were also experienced on the side of the coup-plotters. According to Prime Minister Y1ldırım's declaration a month after the incident, 36 putschists were killed and 49 coup-plotters were apprehended wounded (İHA 2017).

These battles of the night show that security sector institutions had indeed become the frontlines of political conflict as a legacy of the developments that took place over the previous decade. Counterfactual exercises lead to the conclusion that if Gülenists were not promoted and secular officers were not dismissed through Balyoz and other trials, the 15 July coup attempt would not have been staged. If the MiT had not informed the general staff of 
the possibility of a coup, the putschists would not have started their plans in the early hours of the night when millions of citizens were out in the busy centres of Istanbul and Ankara, and able to be mobilized. If thousands of Gülenists were still in the police forces, perhaps they would have also joined the coup shifting the balance in favour of the putschists. Likewise, if the majority of the armed forces, including the general staff, were not loyal to the regime, the entire force of the military might have been used against the government. In short, if the security sector changes of the previous decade had not been made, politics in Turkey would be very different today.

\section{The Aftermath of the Coup and Lessons Unlearned}

One of the first reactions of the government after the coup attempt was to declare a state of emergency (Olăganüstü Hal, OHAL) on 20 July 2016. OHAL has been extended seven times until being suspended in July 2018. Most government decisions, as well as purges from public institutions after July 2016 were carried out by presidential decrees based on OHAL rules. In one year, 50,510 people were arrested, including 8,815 police officers, 169 generals/admirals and 7,098 military personnel from the rank of colonel down. Significant expulsions have also been carried out to dismiss people from public sector jobs, reaching almost 145,000 officials and 5,000 academics in one year (Hürriyet 2017).

Not surprisingly, one of the institutions that has been affected the most by purges is the military. In one year, 150 generals/admirals and nearly 4,300 officers were dismissed out of total of around 7,600 military personnel that lost their posts (Diken 2017). These numbers are in accord with the official numbers of military personnel that participated in the coup and that was provided by the General Staff shortly after 15 July. 8,651 soldiers were suspected of having taken part in the attempt, which made up 1.5 percent of the armed forces. Included in 
these numbers were 2,885 (33 percent) conscripts and students, who were probably only following orders and unaware that they were participating in a coup (BBCTürkçe 2016). Involvement levels were highest among middle ranking officers, which gives credibility to the idea that the Balyoz and espionage trials were used to infiltrate these ranks. Among the 220 brigadier generals, for instance, around 33 percent was accused of taking part in the coup whereas among the 70 major generals only 14 percent conspired in the putsch (Gürcan 2016a). The air force, which makes up 8 percent of the Turkish Armed Forces, constituted 23 percent of those who were purged (Diken 2017). This is also in line with the fact that the air force was involved in the coup more than the other services.

There is no doubt that the purges will have long-term effects on the military. It was reported that there was a shortage of generals and pilots (Gürcan 2016b; Eş 2017), resulting in the readmission of a number of officers who were purged with the previous trials (Hürriyet 2016c), and the mandatory recall of retired pilots (Gürcan 2017a). In the aftermath of the 2017 YAŞ meeting, it also became clear that the government would be more involved with senior level military advancements (Selvi 2017), facilitated also by a new decree that allows for faster promotions (Gürcan 2017a). Overall, these decisions indicate that recruitment and promotion patterns will continue to be disrupted within the military and problems will continue in the unity of the armed forces.

Another issue with the purges is that among the public all of those who were dismissed are being treated as FETÖ members. However, a direct link between a number of accused officers and the Gülen movement was not clearly established. This has led some commentators to argue that officers who had personal reasons or other ideological affiliations, such as secularists and Kemalists, also joined the coup along with the Gülenists (Gürcan 2016a; Cizre 2016). The overgeneralization of all suspects as FETÖ members repeats 
the mistake of previous coup trials. Everybody is tarred with the same brush, potentially leading to grievances that can be carried into the future among active service personnel.

Aside from the purges, the government has also continued to introduce modifications to the security sector though three important sets of decrees. The first set of decrees (numbers 668 and 669) were announced shortly after the coup with the aim of overhauling the military (Resmi Gazete 2016a, 2016b). Military high schools were closed down and substituted with civilian high schools. This allowed for graduates of regular and religious high schools to progress into a military career. War colleges were replaced by the National Defence University, which was then subsumed under the authority of the ministry of national defence. The land, navy and air forces were made responsible to the minister of defence while the general staff came under the direction of the president. This amendment weakened the general staff in terms of its authority over the commanders and allowed for the president and the prime minister to give direct orders to the heads of the forces. The autonomy of military hospitals was also cancelled, bringing them under the control of the ministry of health. Finally, some of the remaining responsibilities of the general staff regarding the gendarmerie and the coast guard were abolished and the ministry of interior's authority over the services was increased (IISS 2017; Hürriyet 2016d).

The second set of changes was introduced in August 2017 with decree number 694 (Resmi Gazete 2017). With the new decree, MIT was brought under the control of the president, with the president absorbing all the powers of the prime minister that were introduced in 2012 and 2014. In this way, MIT continued to be responsible to Erdoğan himself, first as the prime minister and now as president. The decree also established that the National Intelligence Coordination Board, which oversees the activities of ministries and state institutions on intelligence matters, is chaired by the president. Following the coup attempt, the general staff and MIT blamed each other for the intelligence gap. MIT cited its 
inability to enter military units as a reason, while the general staff argued that it had no control over its personnel once they left their stations (Ergin 2017). The new decree resolved the matter in favour of MIT and the agency was given unequivocal authority to carry out intelligence activities within the armed forces. The autonomy of the military in the judiciary was eradicated as well. All military courts were abolished, except for magistrates dealing with discipline crimes during war times. A final provision of the decree dealing with the security sector was the creation of around 30,000 new posts in the police services (Gürcan 2017a).

The third set of decrees was announced in July 2018 after the general elections and shortly before OHAL was suspended (Cumhuriyet 2018). The decrees changed the composition of YAŞ, increased the number of civilian government officials in the meetings and brought it under the control of the president. The general staff also came under the ministry of defence, but the president received the power to give direct orders to the general staff and commanders, who are now obligated to follow the orders immediately. It was also reiterated that the commanders and the general staff were separately responsible to the minister of defence. Although bringing the military under the ministry of defence is a requirement of any civilian regime, the current minister is the former chief of the general staff during the coup, Hulusi Akar. This is the first military officer in the position since the 1960 coup and after 32 civilian ministers (Gazetevatan 2018). The changes that have taken place in the security sector since the coup attempt resemble the amendments that were made since 2008. As naturally expected, large scale purges and trials are taking place in the military and the autonomy of the armed forces in several areas is being curbed further. At the same time, there is a chance for senior level promotions to be based on political criteria. The same pattern is expected to be followed in the police services, as well as MIT, which has also been anchored to the presidency with more internal security duties. 
Similar strategies of civilianizing the security sector by bringing it under the monopoly of the government did not prevent the 15 July coup attempt. Rather than keeping the security sector on a short leash, a longer-term coup-proofing strategy should entail the creation of a liberal democratic legal framework, where not only the presidency, but also the parliament, civil society organizations and an independent judiciary would have oversight and control functions. ${ }^{5}$ Despite the horrors of the coup experience, this unfortunately seems to be a lesson that has not yet been learned.

\section{Conclusion}

This chapter has argued that the security sector has been on the agenda of the Turkish government since it first won the elections in 2002. Since 2007, this has been the main area of contestation between the secularists, the AKP government and the Gülen movement. The costs of this conflict have been dire for the entire country and for many who were killed, for hundreds of individuals, who have been wrongly accused of plotting coups in the last decade and imprisoned, and thousands who have been purged from their duties. It is clear that the policies that have been followed in the armed forces, the intelligence agency and police have not increased the security of the citizens, the government or the president. It is also clear that the security sector will continue to take centre stage and will continue to hold the key to the future of Turkey's domestic and foreign policy.

\section{Notes}

\footnotetext{
${ }^{1}$ For an overview of the Turkish military in politics, see (Hale 1994).

${ }^{2}$ Most of the chronology of the events is based on the author's personal notes. For alternatives, see (Hürriyet Daily News 2016; 15 Temmuz Dosyası 2018).
} 
${ }^{3}$ For an overview of the evidence based on the indictments, see the series of 21 editorials written by Sedat Ergin, with the name "15 Temmuz ve Akıncı Üssü" in Hürriyet. The first editorial was published by Ergin (2017a) and the last one by Ergin (2017b).

${ }^{4}$ For the importance of such signalling, see (Singh 2014).

${ }^{5}$ For the difference between "civilianization through monopolization" and "civilianization through democratization," see (Gürcan 2017b).

\section{Bibliography}

Aydıntaşbaş, Asl1. 2017. "15 Temmuz Muhasebesi [15 July Accounting]" EUObserver, January 17. https://euobserver.com/foreign/136568

Bulur, Sertaç, and Fatih Çakmak. 2016. "İçişleri Bakanı Ala: 17-25 Aralık Sonrası 3 bin 785 Kişi Görevden Alındı [Interior Minister Ala: After 17-25 December 3.785 People Has Been Dismissed" Anadolu Agency, August 25. https://www.sabah.com.tr/ gundem/2016/08/25/17-25-aralik-sonrasi-3-bin-785-kisiyi-gorevden-alindi

Eş, Sertaç. 2017. "Fiilen 'Tuğbay’ Rütbesi” ['Brigadier' Rank as Virtually].” Cumhuriyet, July 10. http://www.cumhuriyet.com.tr/haber/turkiye/777788/Fiilen_T ugbay_rutbesi.html

Ceyhan, Bülent. 2012. "KCK, MİT'in Gözetiminde Oluştu! [KCK was Formed Under the Supvervision of MIT]." HaberTürk, February 9. http://www.haberturk.com/gunde $\mathrm{m} /$ haber/714093-kck-mitin-gozetiminde-olustu

Cizre, Ümit. 2016. “Turkey in a Tailspin.” Middle East Research and Information Project (MERIP), August 10. http://www.merip.org/mero/mero081016

Ergin, Sedat. 2017. "15 Temmuz ve İstihbarat 5: Darbe İstihbaratında Gri Alana Girmek [July 15 and Intelligence 5: Entering a Gray Space in Impact Intelligence].” Hürriyet, July 1. http://www.hurriyet.com.tr/yazarlar/sedat-ergin/15-temmuz-veistihbarat-5-darbe-istihbaratinda-gri-alana-girmek-40505862

Ergin, Sedat. 2016a. "O Albaylar Gitti Darbeciler Geldi [That Colonels Went Putchists Came]." Hürriyet, July 22. http://www.hurriyet.com.tr/yazarlar/sedatergin/o-albaylar-gitti-darbeciler-geldi-40164262

Ergin, Sedat. 2016b. "15 Temmuz ve Hava Kuvvetleri (1) - Bir Hava Kuvveti Nas1l Ele Geçirilir [July 15 and Air Force (1) - How to Handle an Air Force]." Hürriyet, September 21. http://www.hurriyet.com.tr/yazarlar/sedat-ergin/bir-hava-kuvveti-nasilele-gecirilir-40585466

Ergin, Sedat. 2017a. “15 Temmuz ve Akıncı Üssü (1): Bir Hava Üssünde Olağan Şüpheliler [15 July and Akıncı Base (1): Ordinary Suspects at an Air Force Base]." Hürriyet, July 11. http://www.hurriyet.com.tr/yazarlar/sedat-ergin/akinci-ussu-ve-15temmuz-1-bir-hava-ussunde-olagan-supheliler-40515992

Ergin, Sedat. 2017b. “15 Temmuz ve Akıncı Üssü (21): Darbe için Keşif Uçağ1 Kaldırmak [15 July and Akıncı Base (21): Taking off an Expedition Air Craft for 
Putsch]." Hürriyet. August 19. http://www.hurriyet.com.tr/yazarlar/sedat-ergin/15temmuz-ve-akinci-ussu-21-darbe-icin-kesif-ucagi-kaldirmak-40545482

Ergin, Sedat. 2017c. “Kemal Batmaz Pensilvanya'da Fethullah Gülen'in Yanında Kalmış [Kemal Batmaz Stayed With Fethullah Gülen in Pennsylvania].” The Washington Post, May 15. https://www.washingtonpost.com/opinions/globalopinions/the-turkey-i-no-longer-know/2017/05/15/bda71c62-397c-11e7-8854$21 \mathrm{f} 359183 \mathrm{e} 8 \mathrm{c} \_$story.html?utm_term $=.50 \mathrm{~b} 125 \mathrm{ec} 18 \mathrm{bb}$

Ergin, Sedat. 2017d. “15 Temmuz ve Hava Savaşları (3): Hava Sahasında Köşe Kapmaca Nasil Oynanır? [July 15 and Air Wars (3): How to Play Corner Goblet on Airborne?]" Hürriyet, August 22. http://www.hurriyet.com.tr/yazarlar/sedat-ergin/15temmuz-ve-hava-savaslari-3-hava-sahasinda-kose-kapmaca-nasil-oynanir-40557466

Ergin, Sedat. 2017e. "15 Temmuz ve Hava Savaşları (8): Darbenin Havadaki Birinci Kirılma Noktas1 [July 15 and Air Wars (8): First Breakpoint of Putsch in the Air]." Hürriyet, August 29. http://www.hurriyet.com.tr/yazarlar/sedat-ergin/15-temmuz-vehava-savaslari-8-darbenin-havadaki-birinci-kirilma-noktasi-40564285

Entous, Adam, and Joe Parkinson. 2013. “Turkey's Spymaster Plots Own Course on Syria.” The Wall Street Journal, October 10. http://www.wsj.com/articles/SB1000142 4052702303643304579107373585228330

Ignatius, David. 2013. "Turkey Blows Israel's Cover for Iranian Spy Ring." Washington Post, October 17. http://www.washingtonpost.com/opinions/davidignatius-turkey-blows-israels-cover-for-iranian-spy-ring/2013/10/16/7d9c1eb2-368611e3-be86-6aeaa439845b_story.html

Gülen, Fethullah. 2017. "The Turkey I No Longer Know.” The Washington Post, May 15. https://www.washingtonpost.com/opinions/global-opinions/the-turkey-i-no-lon ger-know/2017/05/15/bda71c62-397c-11e7-8854-21f35918 3e8c_story.html?utm_te $\mathrm{rm}=.50 \mathrm{~b} 125 \mathrm{ec} 18 \mathrm{bb}$

Gürcan, Metin. 2016a. "Bir Darbe Girişiminin Anatomisi [Anatomy of Putsch Attempt].” T24, July 17. http://t24.com.tr/yazarlar/metin-gurcan/bir-darbegirisiminin-anatomisi, 15059

Gürcan, Metin. 2016b. "How Post-Coup Purges Depleted Turkey's Military.” AlMonitor, September 16. http://www.al-monitor.com/pulse/originals/2016/09/turkeymilitary-needs-two-year-fill-ranks-emptied-by-purge.html

Gürcan, Metin. 2017a. "Erdogan Hastens Executive Presidency with New Decree." Al-Monitor, August 30. https://www.al-monitor.com/pulse/originals/2017/08/turkeyemergency-decree-redesigns-vital-intstitutions.html

Gürcan, Metin. 2017b. "Never Again! But How? State and the Military in Turkey after July 15." Istanbul Policy Center, April. http://ipc.sabanciuniv.edu/wpcontent/uploads /2017/04/Never-Again_Metin-Gurcan.pdf

Hale, William. 1994. Turkish Politics and the Military. Abindgon: Oxon, and New York: Routledge. 
Hamsici, Mahmut. 2017. "MIT T1rları Davas1 [The Case of MIT Trucks]."

BBCTürkçe, July 15. http://www.bbc.com/turkce/haberler-turkiye-40275619

Kırkeser, Serpil. 2013. "Ergenekon Davasında 5 Y1lın Özeti [Ergenekon Case Summary of 5 Years]. Radikal, July 25. http://www.radikal.com.tr/turkiye/ergenekondavasinda-5-yilin-ozeti-1143366/

Karataş, Bahri. 2013. “Askeri Casusluk İddianamesinde İlginç Detaylar [Interesting Details in Military Espionage Indictment]. Hürriyet, January 23. http://www.hurriyet. com.tr/askeri-casusluk-iddianamesinde-ilginc-detaylar-22416209

Rettman, Andrew. 2017. "Gulen did not order Turkey coup, EU spies say." EUObserver, January 17. https://euobserver.com/foreign/136568

Saymaz, İsmail. 2018. "Ergenekon Soruşturmas1 11 Y1l Sonra Kapand1.” Hürriyet, 28 June. http://www.hurriyet.com.tr/gundem/ergenekon-sorusturmasi-11-yil-sonrakapandi-40879547

Singh, Naunihal. 2014. Seizing Power: The Strategic Logic of Military Coups. Baltimore: John Hopkins University Press.

Selvi, Abdulkadir. 2017. "Yüksek Askeri Şûra'nın Perde Arkası [Behind the Scenes of the Supreme Military Council]." Hürriyet, August 3. http://www.hurriyet.com.tr/ya zarlar/abdulkadir-selvi/yuksek-askeri-s-ranin-perde-arkasi-40538807

Taş, Hakk1. 2018. "The 15 July Abortive Coup and Post-Truth Politics in Turkey." Southeast European and Black Sea Studies, 18, 1 (2018), https://doi.org/10.1080/14683857.2018.1452374.

Toker, Çiğgem. 2015. “İç Güvenlik Paketi ve 'Jandarma' Rahatsızlığı [Internal Security Package and 'Gendarmerie' Discomfort].” Cumhuriyet, February 11. http://www.cumhuriyet.com.tr/koseyazisi/211263/ic_Guvenlik_Paketi_ve_Jandarma _Rahatsizligi.html

Usta, Ayşegül, and Seyit Erçiçek. 2012. "Balyoz Davasında Kararlar Açıklandı [Sledgehammer Case Announced]." Hürriyet, September 21. http://www.hurriyet.com .tr/gundem/balyoz-davasinda-kararlar-aciklandi-21514988

“7 Yeni Cumhurbaşkanlığı Kararnamesi Yayımlandı: Berat Albayrak YAŞ Üyesi Oldu [7 New Presidential Decrees were Published: Berat Albayrak Has Become a Member of YAŞ]." Cumhuriyet, 15 July.

http://www.cumhuriyet.com.tr/haber/siyaset/1027010/7_yeni_Cumhurbaskanligi_Kar arnamesi_yayimlandi_Berat_Albayrak_YAS_uyesi_oldu.html

"Askeri Casusluk Davasında Beraat Kararı [Military Espionage Decision on Acquittal]." 2016a. Hürriyet, February 26. http://www.hurriyet.com.tr/gundem/askericasusluk-davasinda-beraat-karari-40060707

"Başbakan Açıkladı: Kaç Darbeci Öldürüldü? [Prime Minister Announces: How Much Putschist Killed?]" 2016. Ihlas Haber Ajansı (IHA), August 17. http://www.iha .com.tr/haber-basbakan-acikladi-kac-darbeci-olduruldu-580952/ 
"Balyoz'a 40 Dakikada Beraat [Acquittal to Sledgehammer in 40 Minutes]." 2015. Hürriyet, April 1, http://www.hurriyet.com.tr/balyoz-a-40-dakikada-beraat-28612036

"Balyoz Davası Nedir? [What is Sledgehammer Case?]" 2012. Hürriyet, September 21. http://www.hurriyet.com.tr/gundem/balyoz-davasi-nedir-21514407

“Bir Y1llık Bilanço: 15 Temmuz'un Ardından TSK'dan 7 bin 655 Personel İhraç Edildi [One Year Balance Sheet: 7.655 Personnel Were Extruded from TSK].” 2017. Diken, July 12. http://www.diken.com.tr/bir-yillik-bilanco-15-temmuzun-ardindantskdan-7-bin-655-personel-ihrac-edildi/

"Darbelere Geçit Yok! İlelebet Demokrasi [No Permission to Coups! Forever Democracy]." 2017. Hürriyet, July 15. http://www.hurriyet.com.tr/darbelere-gecityok-ilelebet-demokrasi-40520690

"Devlet İstihbarat Hizmetleri ve Milli İstihbarat Teşkilatı Kanununda Değişiklik Yapilmasina Dair Kanun [Law on the Amendment of the Law on the State Intelligence Services and the National Intelligence Organization]."2012. Türkiye Büyük Millet Meclisi (TBMM), February 17. http://www.tbmm.gov.tr/kanunlar/k627 8.html

"Devlet İstihbarat Hizmetleri ve Milli İstihbarat Teşkilatı Kanununda Değişiklik Yapılmasina Dair Kanun [Law on the Amendment of the Law on the State Intelligen ce Services and the National Intelligence Organization]." 2014. Türkiye Büyük Millet Meclisi (TBMM), April 14. http://www.tbmm.gov.tr/kanunlar/k6532.html

"Ergenekon Davası Yeniden Başladı [Ergenekon Case Resumed]." 2017. TRTHaber, June 21, http://www.trthaber.com/haber/gundem/ergenekon-davasi-yeniden-basladi320860.html

"Ergenekon Davasında Generallere Müebbet [Life Imprisonment for Generals in Ergenekon Case]." 2013. BBCTürkçe, August 5. https://www.bbc.com/turkce/h aberler/2013/08/130805_ergenekon_kararlar

"Işık Koşaner Neden İstifa Ettiğini Açıkladı [Işık Koşaner Explained Why He Resigned]." 2016b. Hürriyet, October 26. http://www.hurriyet.com.tr/gundem/isikkosaner-takip-ediyorsun-ama-yapacak-bir-sey-yok-40259804

“İç Güvenlik Paketi’nde Öne Çıkan Maddeler [Prominent in Internal Security Package].” 2015. BBCTürkçe, February 3. http://www.bbc.co.uk/turkce/haberler/2015 /02/150203_tasari_basliklar

“İsim İsim 15 Temmuz Şehitleri [15 July Martrys’ Name List].” 2017. Posta, July 15. http://mservice.posta.com.tr/isim-isim-15-temmuz-sehitleri-haberi-1315115

"İşte Hulusi Akar'ın darbe komisyonuna gönderdiği yanıtlar [Here are the responses which sent to putsch comission by Hulusi Akar]." CNNTurk, May 30.

https://www.cnnturk.com/turkiye/iste-hulusi-akarin-darbe-komisyonuna-gonderdigiyanitlar 
“Kılıçdaroğlu'ndan Çarpıcı 'Kontrollü Darbe' ve Adil Öksüz Açıklaması: Y11 2014 [Stunning Statement by Kılıçdaroğlu; 'Controlled Putsch' and Adil Öksüz in 2014].” 2017. Cumhuriyet, April 5. http://www.cumhuriyet.com.tr/haber/siyaset/71468

5/Kilicdaroglu_ndan_carpici_kontrollu_darbe_ve_Adil_Oksuz_aciklamasi_Yil_2 014 ...html

“Kılıçdaroğlu: Hükümet darbeyi biliyordu, çocuk kandırmasınlar [Kılıçdaroğlu: Government knew the coup, children do not deceive]." 2017. Birgün, January 14. https://www.birgun.net/haber-detay/kilicdaroglu-hukumet-darbeyi-biliyordu-cocukkandirmasinlar-143086.html

"Kronoloji [Chronology]." 2018. 15 Temmuz Dosyası, https://15temmuzdosyasi.com/kronoloji/

"Kuvvet Komutanlıkları MSB'ye Bağlandı [Force Commands Linked to MSB]." 2016d. Hürriyet, July 31. http://www.hurriyet.com.tr/gundem/kuvvet-komutanliklarimsbye-baglandi-40176771

"Mağdur Oldular, Cezaevinde Yattılar, Beraat Ettiler ve Göreve Dönüyorlar [They Became Victim, Imprisoned, Acquitted and They are returning to their mission]." 2016c. Hürriyet, July 22. http://www.hurriyet.com.tr/magdur-oldular-cezaevindeyattilar-beraat-ettiler-ve-yeniden-atandilar-40163342

“Olağanüstü Hal Kapsamında Alınması Gereken Tedbirler ile Bazı Kurum ve Kuruluşlara Dair Düzenleme Yapılması Hakkında Kanun Hükmünde Kararname [Decree Law on the Measures to be Taken in the Context of the State of Emergency and Regulation on the Implementation Regulations of Some Institutions and Organizations]." 2016a. Resmi Gazete, July 27. http://www.resmigazete.gov.tr/eskil er/2016/07/20160727M2..htm

“Olağanüstü Hal Kapsamında Bazı Tedbirler Alınması ve Milli Savunma Üniversitesi Kurulması ile Bazı Kanunlarda Değişiklik Yapılmasına Dair Kanun Hükmünde Kararname [Decree on the Law on the Taking of Some Measures in the Context of the State of Emergency and the Amendment of the Law of the National Defense University and Some Laws]." 2016b. Resmi Gazete, July 31. http://www.resmiga zete.gov.tr/eskiler/2016/07/20160731-5.htm

“Olağanüstü Hal Kapsamında Bazı Düzenlemeler Yapılması Hakkında Kanun Hükmünde Kararname [Decree on the Implementation of Some Regulations Under the State of Emergency]." 2017. Resmi Gazete, August 25. http://www.resmigazete .gov.tr/eskiler/2017/08/20170825-13.pdf

"Polis Vazife ve Salâhiyet Kanunu, Jandarma Teşkilat, Görev ve Yetkileri Kanunu ile Bazı Kanunlarda Değişiklik Yapılmasına Dair Kanun [Law on Police Duty and Ability Law, Gendarmerie Organization, Duties and Authorities Law and Amendments to Some Laws]." 2015. Türkiye Büyük Millet Meclisi (TBMM), March 27. http://www.tbmm.gov.tr/kanunlar/k6638.html 
“'Savunma'ya 58 Y1l Sonra Asker Bakan [Soldier Minister to 'Defence' after 58 Years]." 2018. Gazetevatan, 11 July. http://www.gazetevatan.com/-savunma-ya-58yil-sonra-asker-bakan-1181740-gundem/

“Timeline of Turkey's Failed Coup Attempt.” 2016. Hürriyet Daily News, July 17. http://www.hurriyetdailynews.com/timeline-of-turkeys-failed-coup-attempt-101711

"TSK: Darbe Girişimine 8,651 asker Katıldı, 35 uçak, 37 helikopter kullanıldı [TSK: 8,651 Soldier Participated in Putsch Attempt, 35 Aircraft, 37 Helicopter Used]." 2016. BBCTürkçe, July 27. http://www.bbc.com/turkce/haberler-turkiye-36904517

"Turkey: Security Bill Undermines Rights Parliament Should Rethink Hasty Measures to Increase Police Powers." 2014. Human Rights Watch (HRW), December 11. http://www.hrw.org/news/2014/12/11/turkey-security-bill-undermines-rights

“Turkey's Spy Agency Granted Extraordinary Powers, as President Gül Approves MIT law." 2014. Hürriyet Daily News, April 25. http://www.hurriyetdailynews.com/ turkeys-spy-agency-granted-extraordinary-powers-as-president-gul-approves-mit-law.aspx ?pageID=238\&nid $=65584$ 